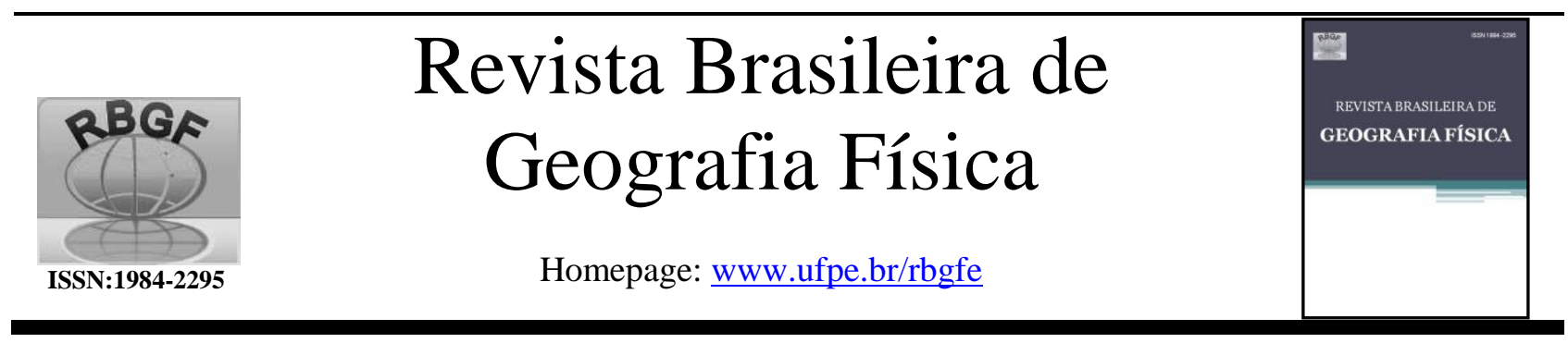

\title{
Análise do EPIA (Estudo Prévio de Impacto Ambiental) referente ao empreendimento Condomínio Green Diamond Residence, com ênfase no recurso ambiental solo
}

\author{
César Costa Sanches ${ }^{1}$, Jorge Ulisses Guerra Villalobos ${ }^{2}$ \\ ${ }^{1}$ Mestrando em Geografia pela Universidade Estadual de Maringá. Especialista em Ensino e Pesquisa na Ciência Geográfica pela UNICENTRO - \\ cesarcosta_1@ @otmail.com. \\ ${ }^{2}$ Doutor em Geografia pela Universidade Estadual de Maringá. Professor da Universidade Estadual de Maringá - villalobos.uem@gmail.com.
}

Artigo recebido em 10/07/2017 e aceito em 03/05/2018

\section{R E S U M O}

No que se refere à temática ambiental, no contexto da legalidade no plano jurídico, a elaboração do EIA/RIMA faz parte do instrumento concreto que serve de suporte para analise de obras e atividades passíveis de qualquer tipo de dano ao ambiente. O presente trabalho consiste no estudo e análise do EPIA (Estudo Prévio de Impacto Ambiental), com base no RIMA (Relatório de Impacto Ambiental) referente ao empreendimento denominado "Condomínio Green Diamond Residence", localizado no município de Marialva/PR, situado a noroeste do estado do Paraná. Tal estudo pretende analisar, sob a perspectiva do geógrafo, o recurso ambiental solo, da área destinada a receber o empreendimento Condomínio Green Diamond Residence, de modo a compreender e diagnosticar o uso adequado de determinadas áreas, compreendendo as suas propriedades no que tange a declividade, topografia, clima, precipitação e tipo de vegetação presente na área estudada. Deste modo, é possível compreender que algumas localidades possuem solos inapropriados para fins de construção civil, como é o caso da vertente referente a área abordada no presente trabalho. Com isso, destacase a contextualização das informações referentes ao contexto pedológico, geomorfológico, climatológico, fitogeográfico com a representação do modelo da superfície de terreno, compreendendo que nas áreas planas e mais baixas, próximo ao curso hídrico, nota-se a existência de um solo com caráter hidromórfico. Com isso, percebe-se que algumas informações referentes a alguns impedimentos para sua construção foram omitidas e não informadas no EPIA da área de estudo.

Palavras-chave: Solo. Impacto Ambiental. Hidromórfico

\section{Analysis of the EIA (Environmental Impact Assessment) related to the Green Diamond Residence Condominium, with emphasis on the soil environmental resource.}

\begin{abstract}
A B S T R A C T
About to environmental issues in the context of legality in judicial terms, the preparation of the EPIA / RIMA is part of the concrete instrument that serves as a support for the analysis of works and activities subject to any kind of harm to the environment. The present work is the study and analysis of the EIA (Environmental Impact Assessment), based on the EIR (Environmental Impact Report) for the enterprise called "Condomínio Green Diamond Residence", located in the municipality of Marialva / PR, situated northwest the state of Paraná. This study aims to analyze, from the perspective of the geographer, the environmental resource soil of the area for receiving the project "Condomínio Green Diamond Residence", in order to understand and diagnose the proper use of certain areas, including their properties in that concern the slope , topography, climate, precipitation and type of vegetation present in the study area, so you can understand that some locations have soil unsuitable for construction purposes, as is the present case. With that, that is the contextualization of the information concerning the pedological context, geomorphological, climatic, phytogeographic with the representation of the model of the ground surface, realizing that in flat areas and lower ground, near the water course, there is the existence of a soil with hydromorphic character. Thereby, it is noticed that some information related to some impediments to its construction were omitted and not reported in the EPIA of the study area.
\end{abstract}

Keywords: Hydromorphic. Environmental Impact. Soil. 


\section{Introdução}

Podemos perceber que principalmente a partir da década de 70 , a preocupação com a utilização dos recursos naturais aumentou significativamente no Brasil, criando em 1981 a Política Nacional do Meio Ambiente.

Além disso, em 1988 por meio da Constituição Federal, foram criadas condições políticas que obrigaram que os entes políticos do país tivessem uma posição mais ativa $\mathrm{e}$ participativa nas questões ambientais em diferentes escalas espaciais, iniciando então programas e políticas públicas mais adaptadas à realidade e as singularidades presentes em cada região. Assim, a evolução da legislação ambiental brasileira, nos últimos anos, estabeleceu novas regras e normas mais coerentes com relação às particularidades e à realidade do país.

No que tange a temática ambiental e do contexto da legalidade, a elaboração do EPIA/RIMA faz parte do instrumento concreto que serve de suporte para análise de obras e atividades passíveis de causarem algum tipo de dano ao ambiente. Tal estudo consiste em um documento técnico, no qual se registra as consequências e danos ocasionados ao ambiente devido, principalmente, a construção de um determinado empreendimento, identificando de forma quantitativa e qualitativa os possíveis impactos ambientais, listando juntamente as medidas mitigadoras.

Deste modo, tal documento é de suma importância no que diz respeito às medidas adequadas que servem de maneira preventiva contra os danos e atividades ocasionadas pelos empreendimentos, evitando e minimizando as possíveis alterações negativas ao meio ambiente.

Foi introduzida, no Brasil, em 1981, a Política Nacional do Meio Ambiente (PNMA), sendo que em 1986, pela resolução do Conselho Nacional de Meio Ambiente (CONAMA) $n^{\circ}$. 001/ 86 foram definidas as atividades sujeitas a elaboração do Estudo Prévio de Impacto Ambiental (EPIA), bem como as diretrizes gerais para a elaboração do estudo e suas atividades técnicas em relação ao prognóstico e diagnóstico da área abordada.

De acordo com a Constituição Federal de 1988, (artigo 225. §1 ${ }^{\circ}, \mathrm{VV}$ ), mediante ao Código Estadual de Meio Ambiente, o licenciamento para a construção, instalação, ampliação, alteração e operação de empreendimentos ou atividades utilizadoras de recursos ambientais considerados de significativo potencial de degradação ou poluição, dependerá da apresentação do Estudo Prévio de Impacto Ambiental (EPIA) e do respectivo Relatório de Impacto Ambiental
(RIMA). Deste modo, pode-se observar que o Estudo Prévio de Impacto Ambiental consiste em um documento legal de suma importância, no que tange ao planejamento e conservação ambiental, por meio de previsões e análises dos danos ambientais, diagnósticos da área, definições de medidas mitigadoras necessárias e as atividades de acompanhamento e monitoramento referentes aos possíveis impactos ocasionados pela implantação do empreendimento.

O presente trabalho consiste no estudo e análise do EPIA (Estudo Prévio de Impacto Ambiental), referente ao empreendimento denominado "Condomínio Green Diamond Residence", localizado no município de Marialva/PR, que visa analisar, diante das competências do geógrafo presentes na Lei $\mathrm{N}^{\circ} 6.664 / 79$, o meio físico da área do empreendimento.

Diante de tais objetivos, o presente estudo enfatiza os aspectos relacionados as propriedades físicas e estruturais do recurso ambiental solo, com base no diagnóstico ambiental da área e do solo, sendo possível delimitar e identificar as áreas inadequadas e adequadas à realização do empreendimento, diante dos estudos e análises realizadas referentes as suas características topográficas, geomorfológicas, pedológicas e climatológicas.

A Pedologia é um ramo do conhecimento das Ciências da Natureza, que estuda o solo, seu termo vem do grego e latim ped ou pedon (terra onde pisa), e logos (estudo), assim é interessante verificar que tal ciência torna explícita a importância de diferentes fatores responsáveis pela sua gênese e consequentemente suas principais características e propriedades (Neto, 2003).

Diante da Ciência do Solo, dedicada a estudar tal recurso, uma de suas ramificações, a Pedologia, se compromete compreender, principalmente, o solo como um recurso natural, se preocupando também com a origem e sua evolução, morfologia, constituição, classificação e o mapeamento, que se formam, assim, a base de indicação do seu uso adequado, conforme os princípios de proteção ambiental. Sendo assim, são de suma importância os estudos relacionados à conservação dos solos agrícolas, uma vez que-; o homem constantemente tem realizado o seu uso de forma inadequada, causando assim, muitas vezes, danos irreversíveis ao meio ambiente, por meio de atividades e práticas inadequadas ao meio (Lepsch, 2010).

Sob a perspectiva da pedologia, o seu objeto de estudo, o solo, apresenta características singulares que o distinguem de outros recursos naturais. $\mathrm{O}$ solo adquire tais propriedades devido à 
atuação direta e indireta das ações de outros elementos da paisagem que o constituem, assim é competência da pedologia estudar e compreender os processos e mecanismos resultantes em sua gênese e evolução- (Neto, 1987)

Segundo o autor, o recurso ambiental solo de maneira alguma pode ser estudado e analisado isoladamente, pois é de suma importância compreender que tal recurso adquire suas características diante dos processos dinâmicos que regem as relações entre a litosfera, atmosfera, hidrosfera e biosfera.

Em seu trabalho o autor ainda expõe que, o solo constitui elementos de extrema importância, pois recebe a maior carga de água das chuvas, sendo responsável então pelo armazenamento e fornecimento para as plantas, bem como o controle do abastecimento dos lençóis freáticos que originam os cursos hídricos.

Segundo o autor, o uso do solo realizado pela atividade antrópica é destinada para diversos fins, muitas vezes, de maneira inadequada, como por exemplo, a realização de edificações e construções civis em locais inapropriados ocasionando assim, a degradação do recurso estudado, acarretando inclusive danos e modificações em sua estrutura, alterando de maneira significativa o seu comportamento e a dinâmica das paisagens envolvidas.

Apesar dos vários momentos que vem ocorrendo ao longo da história, a Pedologia se torna assunto de interesse para a sociedade cada vez mais, pois não é possível mais isolar o recurso ambiental solo, de questões como produção de alimentos, fibras e energia, mudanças climáticas, sustentabilidade ambiental, construção civil entre outros. Diante disso, conhecer o solo para então realizar o uso adequado através da otimização de práticas sustentáveis, bem como para executar o planejamento de uso das terras, tornou-se indispensável inclusive para a definição de políticas públicas (Santos, 2013).

A ênfase em realizar processos de classificação dos solos, foi centralizada em analisar as suas propriedades, relacionado principalmente a sua gênese, atrelado juntamente com a atuação de agentes e dos fatores externos que atuam na formação do solo. Diante disso, é possível perceber que com a quantidade de informações que se atualizam constantemente, relacionado ao fácil acesso a diversos tipos de dados, se faz necessária ainda à interpretação destes de modo a compreender de maneira mais objetiva a pedogênese dos solos (Hartemink \& Bockheim, 2012).
Neste trabalho é de suma importância a análise do EPIA (Estudo Prévio de Impacto Ambiental) do empreendimento Condomínio Green Diamond Residence, situado no município de Marialva/PR, no âmbito das competências do Geógrafo, enfatizando os aspectos relacionados com as propriedades pedológicas da área abordada, compreendendo as suas características físicas referente à declividade, topografia, clima, precipitação e tipo de vegetação presente.

Com isso, será possível realizar diagnósticos, com base no meio físico da área abordada, nas propriedades físicas do recurso ambiental solo, caracterizando e identificando assim, as áreas inadequadas para a implantação do devido empreendimento.

Estudos referentes ao conhecimento do recurso ambiental solo, são de suma importância para a competência de diversos profissionais, bem como o geógrafo, que o analisa e estuda de modo a contextualizar suas propriedades físicas e químicas com diversos fatores e fenômenos que atuam direta ou indiretamente nas características deste (Lepsch, 2010).

\section{Material e métodos}

A área abordada no presente estudo, está situada no município de Marialva- PR, localizado no noroeste do estado do Paraná, na região do Terceiro Planalto/ Planalto de Guarapuava como mostra a Figura 1, sendo o lote delimitado a noroeste pelo leito do Ribeirão Pinguim, no qual esta inserido ao sistema da bacia hidrográfica do Rio Ivaí.

A presente área localiza-se no Lote $n^{\circ} 6$ Remanescente, na Gleba Ribeirão Pinguim, contando com uma área de aproximadamente 248,1509 hectares, ou seja, 102,5417 alqueires paulistas, delimitado especificamente entre as coordenadas $23^{\circ} 30^{\prime} 23.55^{\prime \prime}$ S e $51^{\circ} 56^{\prime} 49.24^{\prime \prime}$ ' O (Figura 2).

Segundo o Instituto Nacional de Meteorologia (INMET), as médias de temperatura registradas nos meses mais quentes, são de aproximadamente $22^{\circ} \mathrm{C}$, já as médias dos meses mais frios registram aproximadamente $18^{\circ} \mathrm{C}$, contando ainda com índices de precipitação pluviométrica média de aproximadamente 1.500 $\mathrm{mm} / \mathrm{ano}$, sendo distribuídas e concentradas principalmente nos meses que correspondem à primavera e verão, sendo que nos meses que correspondem as estações referentes ao inverno e outono, o índice pluviométrico apresenta uma queda moderada. 


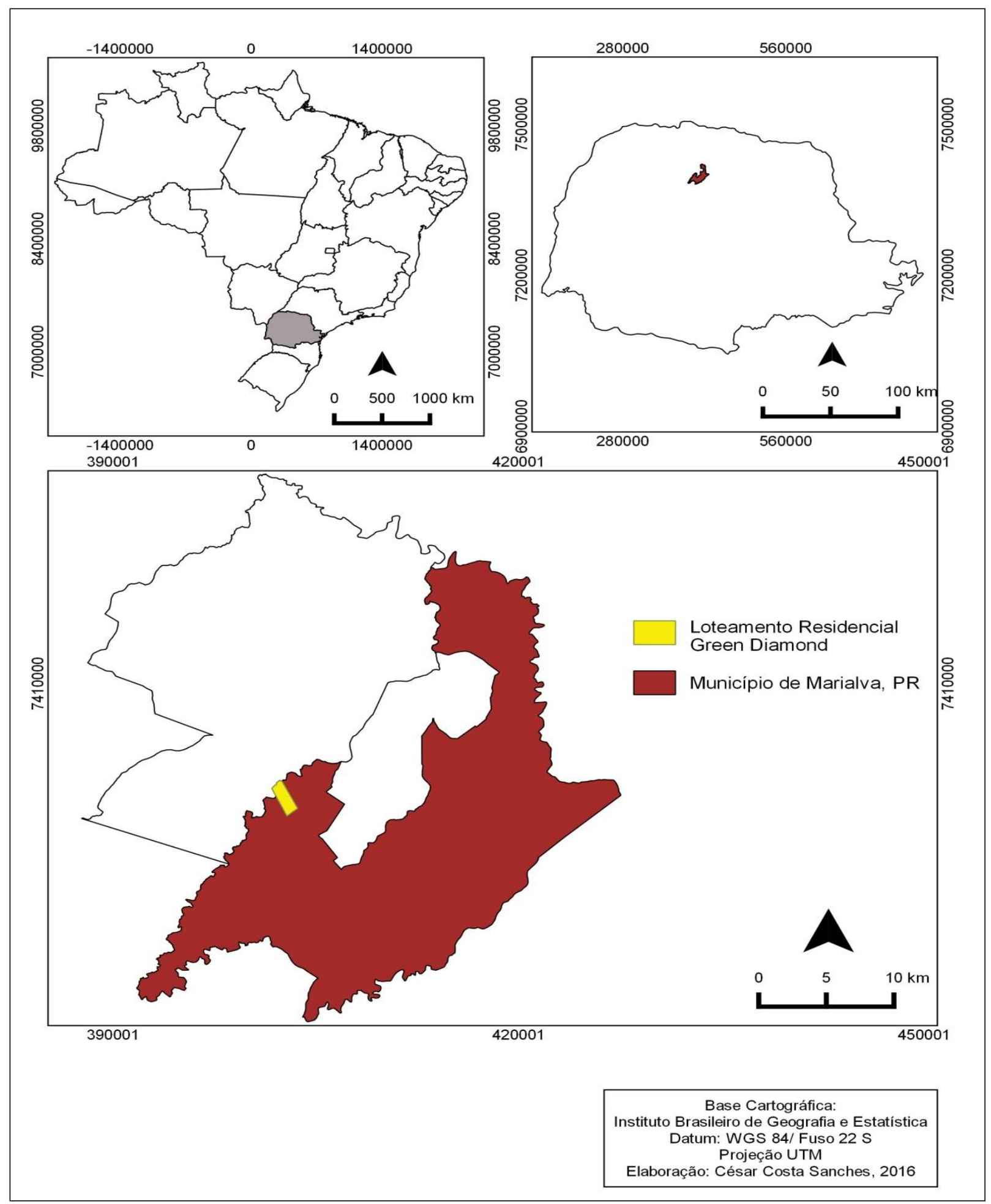

Figura 1. Mapa de localização do Condomínio Green Diamond Residence. 


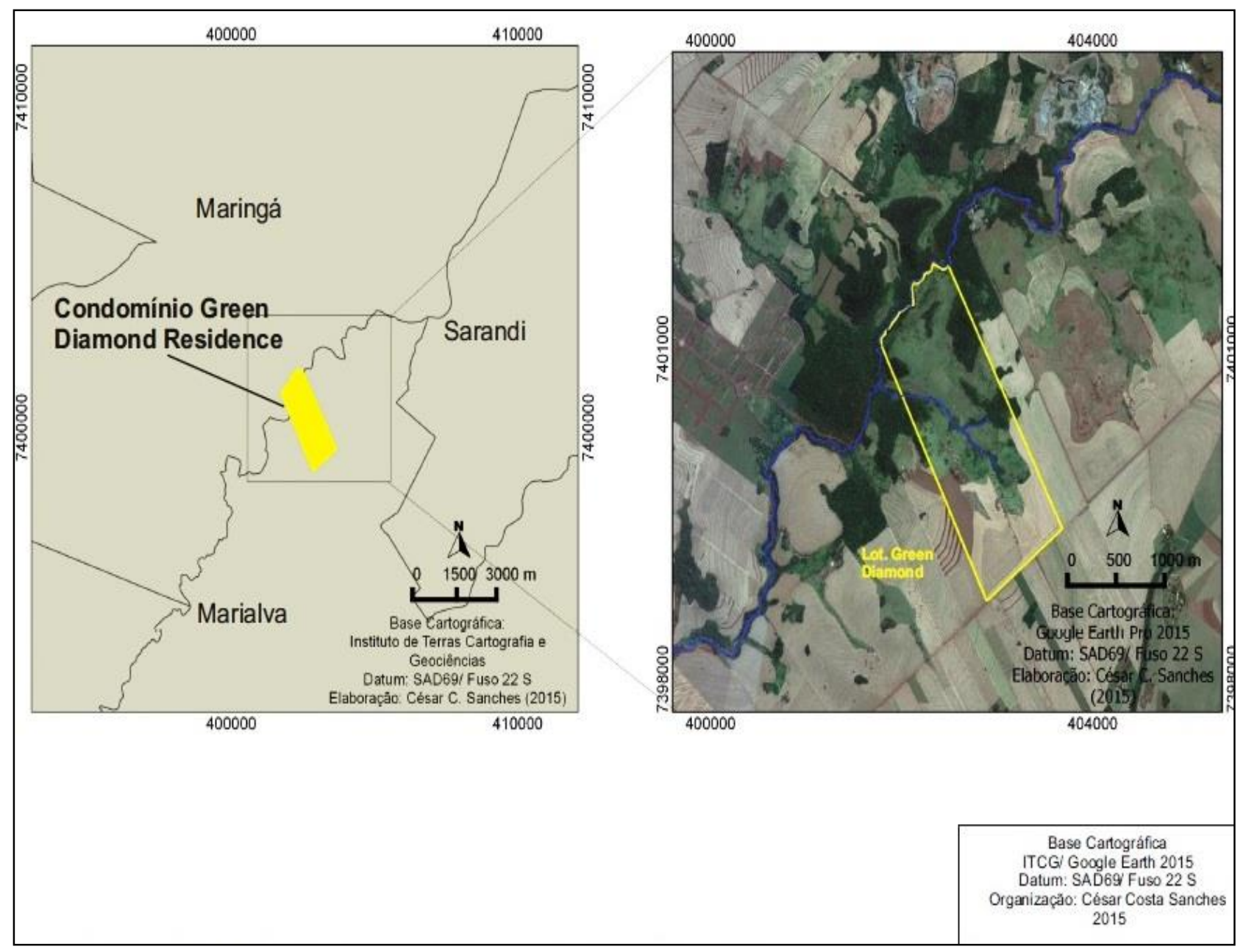

Figura 2: Imagem de satélite da área de estudo.

O tipo de vegetação localizada na região é predominantemente subtropical perenifólia heterogênea, com diferentes espécies de árvores, correspondendo também às formações fitogeográficas denominadas de Floresta Estacional Semidecidual, que possui como característica a influência climática de dois diferentes períodos (chuva e seca), o que faz com que ocorra a perda parcial de suas folhas.

Assim as árvores podem regular seu balanço hídrico, perdendo suas folhas em períodos de menos incidência das chuvas e temperaturas mais elevadas ou recobrindo-se de folhas nos períodos mais chuvosos do ano. No que tange as estruturas em camadas, tal floresta apresenta um estrato arbóreo com dossel (copa) elevado, formado por árvores que podem atingir até 40 metros de altura. Abaixo, o estrato arbustivo, rico em diversidade de espécies vegetais e por fim, a camada herbácea, composta por basicamente por vegetações rasteiras.

Os aspectos físicos propiciam dentro da Floresta Estacional Semidecidual, três subdivisões: Aluvial (matas ciliares que ocorrem associadas nas margens dos rios), Submontana (se desenvolve em solos mais secos, nas regiões abaixo das montanhas), e Montana (ocorre em áreas montanhosas com elevações médias acima de 400 metros de altitude). (Campos \& Filho, 2010)

Segundo dados obtidos por meio do Instituto de Terras, Cartografia e Geociências (ITCG), de uma maneira geral, o município de Marialva caracteriza-se por uma formação de relevo predominantemente ondulado, destacandose o predomínio de solos do tipo Latossolos Vermelhos Distroférrico, Latossolos Vermelhos Eutroférrico, Nitossolo Vermelho Eutroférrico, Neossolos Litólicos Eutróficos, alterando o tipo e caráter de solo de acordo com as características físicas e geomorfológicas da paisagem (Figura 3). 


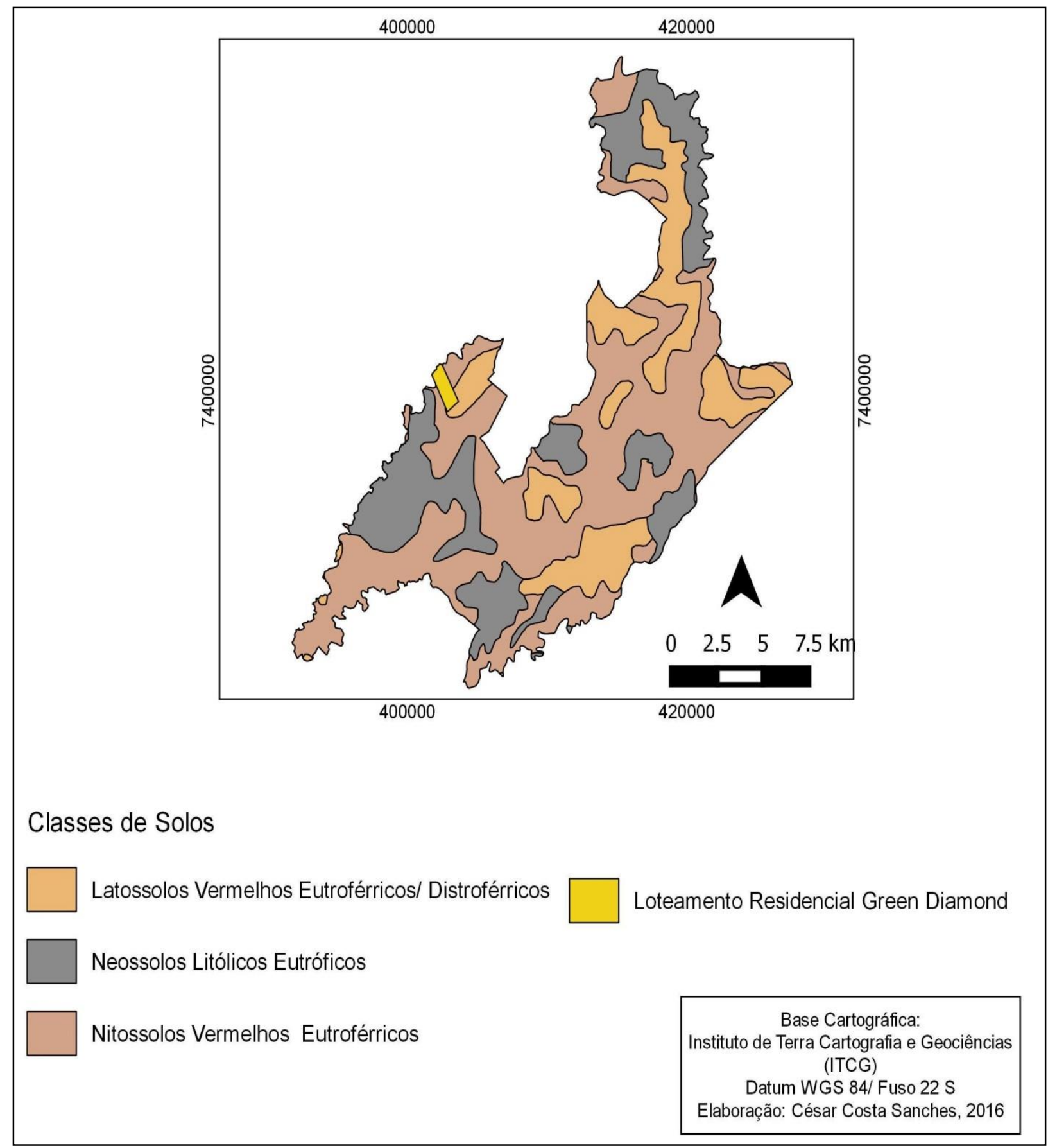

Figura 3. Mapa de solos do município de Marialva-PR.

No que tange aos aspectos geomorfológicos, podemos situar a área abordada no terceiro Planalto paranaense, precisamente situado no município de Marialva, onde se encontra uma área de transição do Planalto de Apucarana para o Planalto de Campo Mourão (Figura 4).

De acordo com Maack (1986) a subunidade morfoescultural denominada de Planalto de Apucarana caracteriza-se por uma grande variação nas cotas altimétricas, variando entre 300 e 920 metros, com maior dissecação e formas predominantes de topos alongados e aplainados, bem como o Planalto de Campo Mourão que forma o divisor dos rios Ivaí e Piquiri e apresenta mesetas características em sua parte mais elevada.

O caráter estrutural das mesetas, tão características do Terceiro Planalto, deriva das estruturas tabulares dos derrames vulcânicos, de maneira que os degraus representam as superfícies entre os empilhamentos sucessivos de lavas. (Archela, et al, 2003) 


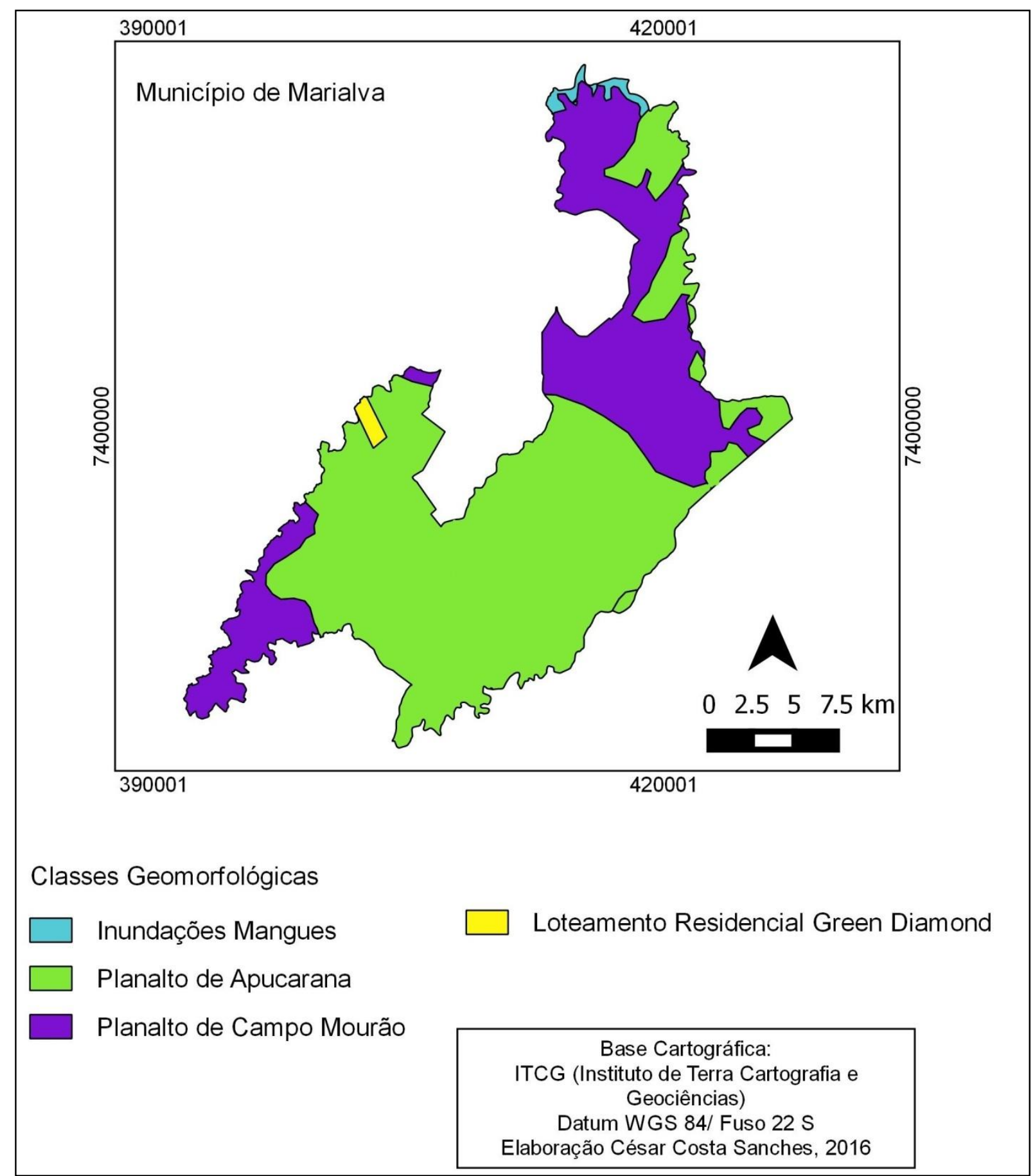

Figura 4. Mapa de geomorfologia do município de Marialva-PR.

Segundo o documento Estudo Prévio de Impacto Ambiental referente ao empreendimento denominado Green Diamond Residence, tal área é caracterizada como um condomínio fechado com 2.508 lotes, composta de área de lazer, saúde e educação, sendo previstas condições de infraestrutura referentes a 80 ruas, 141 cruzamentos, sinalizações de trânsito, rede de esgoto, rede de distribuição de energia elétrica, bem como de água potável.

Segunda dados obtidos no documento referente ao Estudo Prévio de Impacto Ambiental da área abordada (Figura 5), em relação às porcentagens de ocupação do solo por usos e atividades, nota-se que a área líquida das datas corresponde a aproximadamente $45 \%$ do total da área do lote, ou seja a 1.136.012,95 m², já a Área Verde, bem como o Sistema Viário correspondem a aproximadamente $16 \%$, assim a Área de Lazer/Uso Comum possui aproximadamente 14\%, ou seja $367.453 .75 \mathrm{~m}^{2}$, e a área destinada a preservação permanente corresponde a $6,13 \%$, ou seja $152.149,41 \mathrm{~m}^{2}$. 
Figura 5: Áreas com porcentagem de ocupação do solo por usos e atividades.

\begin{tabular}{|l|l|l|}
\hline Descrição & Área $\left.\mathbf{( m}^{\mathbf{2}}\right)$ \\
\hline $\begin{array}{l}\text { Área líquida } \\
\text { das datas }\end{array}$ & 45,78 & $1.136 .012,95$ \\
\hline Área Verde & 16,67 & $413.686,91$ \\
\hline Sistema Viário & 16,61 & $412.205,98$ \\
\hline $\begin{array}{l}\text { Área de Lazer/ } \\
\text { Uso Comum }\end{array}$ & 14,81 & 367.453 .75 \\
\hline $\begin{array}{l}\text { Preservação } \\
\text { Permanente }\end{array}$ & 6,13 & $152.149,41$ \\
\hline $\begin{array}{l}\text { Área Total do } \\
\text { Loteamento }\end{array}$ & 100 & $2.481 .509,00$ \\
\hline
\end{tabular}

Fonte: EPIA/RIMA- Green Diamond Residence, 2013. Adaptação: César Costa Sanches, 2016

Consideramos que o EPIA (Estudo Prévio de Impacto Ambiental) realizado do empreendimento Green Diamond Residence, situado no município de Marialva/PR, é de suma importância para análises e estudos no âmbito das competências do Geógrafo, pois com base em tal documento, é possível compreender as propriedades fisico-geográficas da área abordada, principalmente os aspectos relacionados às suas características pedológicas, de modo a analisar e entender os problemas ambientais referentes à realização de tal empreendimento.

Tal estudo pretende analisar, sob a perspectiva do geógrafo, o recurso ambiental solo, da área destinada a receber o empreendimento Condomínio Green Diamond Residence, de modo a compreender e diagnosticar o uso adequado de determinadas áreas, entendendo as suas propriedades no que tangem a declividade, topografia, clima, precipitação e tipo de vegetação presente na área estudada.

Para a obtenção de dados, inicialmente, foi realizado um levantamento bibliográfico exploratório, a fim de selecionar os materiais a serem utilizados que continham uma maior representatividade dos objetivos propostos num primeiro momento pelo trabalho, bem como obter uma cópia do Estudo Prévio de Impacto Ambiental (EPIA) do empreendimento imobiliário "Green Diamond Residence", junto ao órgão ambiental.

A partir disto, foi possível realizar análises referentes ao uso e ocupação do solo do local do empreendimento no âmbito das competências do geógrafo, dando ênfase aos aspectos relacionados com o recurso ambiental solo. Diante disso, possibilitou-se a realização de relações com base nas informações dos mapas produzidos com as informações contidas nas fotografias do recurso ambiental solo do empreendimento "Green Diamond Residence" de modo a reconhecer características e condições físicas e estruturais inadequadas para a realização de práticas relacionadas as construções civis.

Já para a elaboração de produtos cartográficos, os mapas hipsométricos, de declividade, pedológico, geomorfológico, fitogeográficos e de localização, foram realizados utilizando como base cartográfica mapas e levantamentos já existentes, encontrados em formato digital (*shp), no sítio eletrônico do ITCG, com adaptações usando o software Quantum Gis versão 2.6.1 Brighton.

As informações necessárias à elaboração do mapa de unidades geomorfológicas foi elaborado a partir de informações do Atlas Geomorfológico do Estado do Paraná (MINEROPAR, 2006) e a base digital obtida no sítio eletrônico do ITCG em escala 1:250.000.

O mapa de solos foi elaborado partindo de informações contidas no material digital da EMBRAPA (2008), disponível no sítio eletrônico do ITCG em escala 1:250.000. Já quanto ao mapa de formações fitogeográficas, o mesmo foi elaborado a partir da base digital também disponível do sítio eletrônico do ITCG, bem como o mapa de classificação climática segundo Köppen, 1936.

Para a elaboração do mapa de localização da área de estudo com base numa imagem de satélite, foi utilizada uma base digital em formato (*shp) junto ao sítio eletrônico do ITCG, relacionando suas informações com uma imagem de satélite Landsat 8 , retirada junto ao Google Earth Pro, sendo processadas e georeferenciadas as imagens no software Quantum Gis 2.6.1 Brighton.

$\mathrm{Na}$ confecção dos mapas referentes à modelagem 3D de terreno, foram utilizados dois softwares diferentes para representar da melhor forma as condições físicas da área de estudo, sendo um o SketchUp Make 2014, onde foi possível cotar as curvas de nível coletadas a partir do levantamento topográfico realizado na área, já presentes no arquivo disponibilizado no formato (.dxf) representando assim por meio da ferramenta referente a malha de terreno denominada de "caixa de areia" o terreno, no qual seria instalado o loteamento residencial. Numa outra perspectiva de modelagem de terreno, foi utilizado o software Surfer 8 , utilizando como base um arquivo no formato (.xyz) resultado da conversão de formatos do arquivo referente as curvas de nível digitalizadas e georeferenciadas no Quantum Gis 2.6.1 Brighton, para então gerar no formato por meio da base (.GRID) a representação do terreno em 3D. 


\section{Resultados e discussão}

Diante dos levantamentos realizados, podemos perceber que no município de Marialva, $\mathrm{PR}$, os solos que são representados no material disponibilizado pelo ITCG precisamente numa escala de 1:250.000, são os Latossolos Vermelhos Distroférricos, Latossolos Vermelhos Eutroférrico, Nitossolo Vermelho Eutroférrico e Neossolos Litólicos Eutróficos.

De modo a caracterizá-los, podemos notar que, os Latossolos Vermelhos Distroférricos apresentam propriedades físicas derivados de rochas básicas, solos bem drenados, profundos e bem desenvolvidos, indicando boa permeabilidade devido a sua alta porosidade, condicionando também uma boa permeabilidade, quando em condições naturais ou bem manejados, porém em condições de manejo inadequado podem ocasionar ravinas e pequenas voçorocas. No que tangem ao seu aspecto Distroférrico, diferesem-se dos Eutroférricos por possuírem baixa fertilidade, sendo que ambos apresentam elevados teores de Ferro (AGEITEC, 2014).

Quanto aos Nitossolos Vermelhos Eutroférricos, são solos medianamente profundos, bastante intemperizados e com fraca diferenciação dos horizontes, ou seja, apresenta uma transição gradual ou difusa do horizonte A para o B, acrescentando estrutura com agregados em forma de blocos com nítidas e brilhantes superfícies comumente descritas como cerosidade, seu caráter eutroférrico o caracteriza como um solo fértil com alta concentração de ferro (Lepsch, 2010)

Já os Neossolos Litólicos Eutróficos, são solos de alta fertilidade, porém com pouca ou nenhuma evidência de horizontes pedogenéticos subsuperficiais, sem qualquer tipo de horizonte B diagnóstico. Formam materiais praticamente inertes, sem argilas, e são extremamente resistentes a intempéries, tais solos encontram-se principalmente em área com declives acentuados com relevo movimentado, tendo assim muitas limitações ao uso agrícola, pelo fato de a rocha situar-se a pouca profundidade e apresentar alguns afloramentos (EMBRAPA, 2010).

Nota-se que, diante do sistema de levantamento de dados e informações, realizados pelo Instituto de Terras, Cartografia e Geociências (ITCG) referente ao mapa de solos do estado do Paraná na escala 1:250.000, algumas generalizações e poucos detalhes referentes a dados e informações, no que tange as propriedades físicas e químicas do solo relacionados diretamente com outros aspectos físicos da natureza.

$\mathrm{Na}$ área abordada, referente ao empreendimento "Green Diamond Residence", situado no município de Marialva, PR, pode-se notar por meio da análise e contextualização das informações referentes aos aspectos físicos como: clima, topografia, pedologia, geomorfologia com as fotografias retiradas do perfil do solo nas áreas mais baixas da vertente, que as propriedades físicas do solo apresentam, na verdade, diferentemente do que nos mostra o EPIA/RIMA, um caráter de solo hidromórfico, ou seja, um tipo de solo inadequado para a prática ou realização de qualquer construção civil.

Diante da perspectiva representada pela figura 6 , pode-se notar que a área abordada apresenta uma discrepância topográfica de aproximadamente 100 metros, partindo do pressuposto que sua área mais baixa se encontra a aproximadamente 395 metros de altitude, numa área de planície as margens do Ribeirão Pinguim, e que sua área mais elevada se encontra a aproximadamente 495 metros de altitude, sendo de suma importância ressaltar que na média vertente, nota-se a presença de dois corpos hídricos caracterizados como nascentes do córrego Wenceslau, sendo este caracterizado como afluente da margem esquerda do Ribeirão Pinguim. Diante de tais indicadores, nota-se que na baixa vertente da área delimitada para ser implantado o loteamento, encontra-se uma planície de inundação, oferecendo assim algumas fragilidades quanto ao seu uso, o que não aparece em seu EPIA. 


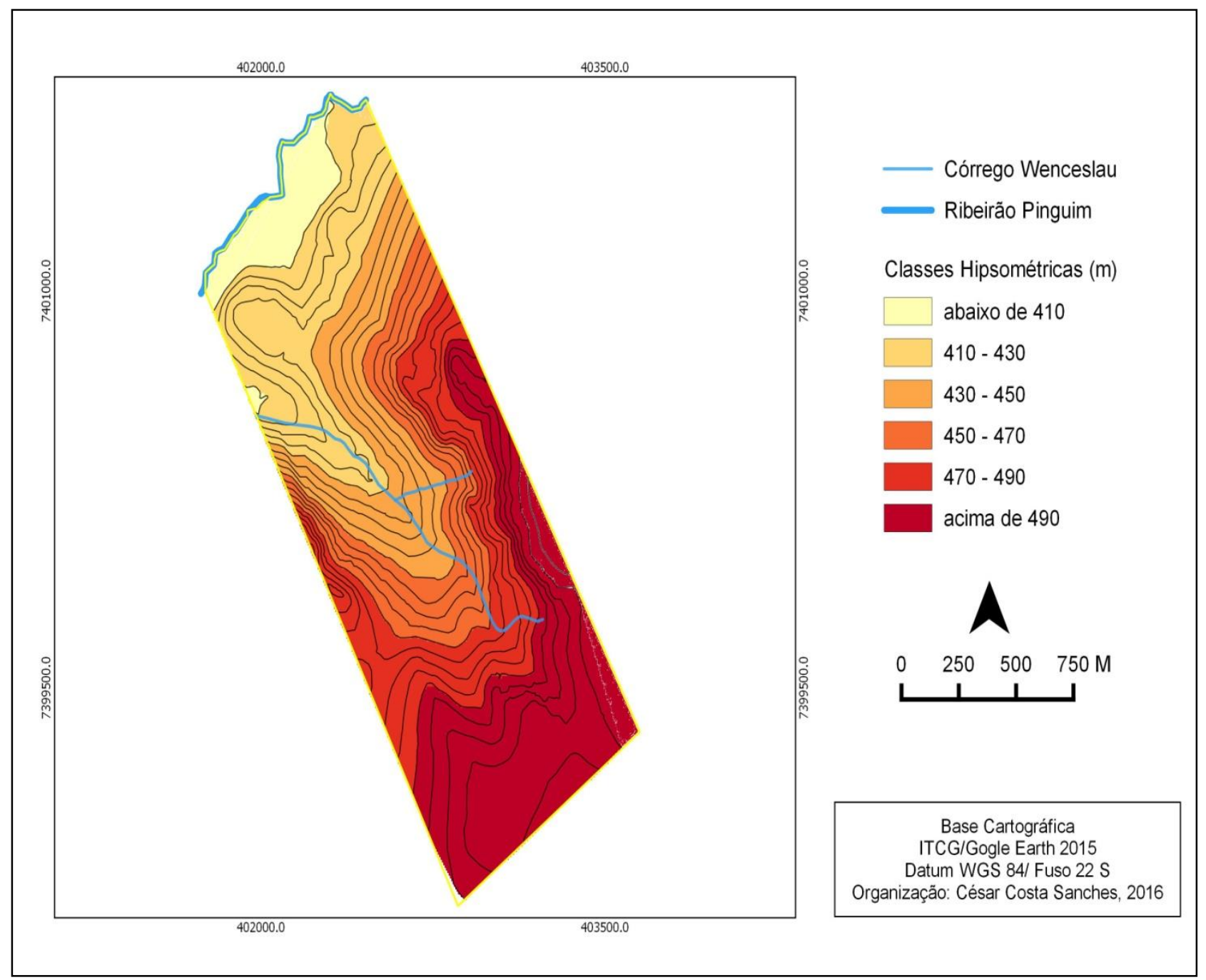

Figura 6: Mapa hipsométrico da área do Condomínio Green Diamond Residence.

No que tange aos aspectos geomorfológicos, nota-se também que, associado às características hipsométricas representadas no mapa de hipsometria, é de suma importância realizar e elaborar um levantamento, de modo a representar as diferentes classes de declividade da área abordada, contextualizando tais dados de modo com que seja possível diagnosticar por meio das análises dos aspectos pedoambientiais a presença de uma planície de inundação, nas áreas mais baixas do loteamento, próximo às curvas cotadas em 395 metros, concomitantes as áreas mais aplainadas as margens do Ribeirão Pinguim, ou seja, com os menores valores de declividade no qual estão representados em porcentagem.

Nota-se na figura 7, que as áreas em que as curvas de nível se apresentam mais espaçadas entre si, comprende-se que são as áreas mais planas da área abordada, representadas com uma declividade inferior a $3 \%$, estando situadas nos extremos do lote.

Contextualizando as informações dos mapas hipsométricos e de declividade percebe-se que as áreas que apresentam um predomínio de declividades mais baixas, estão situadas no topo da vertente e na baixa vertente, próximo aos corpos hídricos que delimitam o fundo do lote.

Além disso, é possível compreender que as áreas com as declividades mais acentuadas com o relevo mais acidentado estão situadas de forma geral nas margens do córrego Wenceslau, bem como, muito próximo as nascentes dos corpos hídricos.

Correlacionando as informações referentes à hipsometria do lote, com as classes de declividade e sua geomorfologia, atrelado também aos aspectos físicos e naturais atuantes da paisagem geográfica, nota-se que principalmente nas áreas planas da baixa vertente, compreende-se um conflito que não fica evidenciado no documento referente ao Estudo Prévio de Impacto Ambiental do empreendimento Green Diamond Residence, que é a existência e a formação de um solo com caráter hidromórfico devido as características já expostas. 


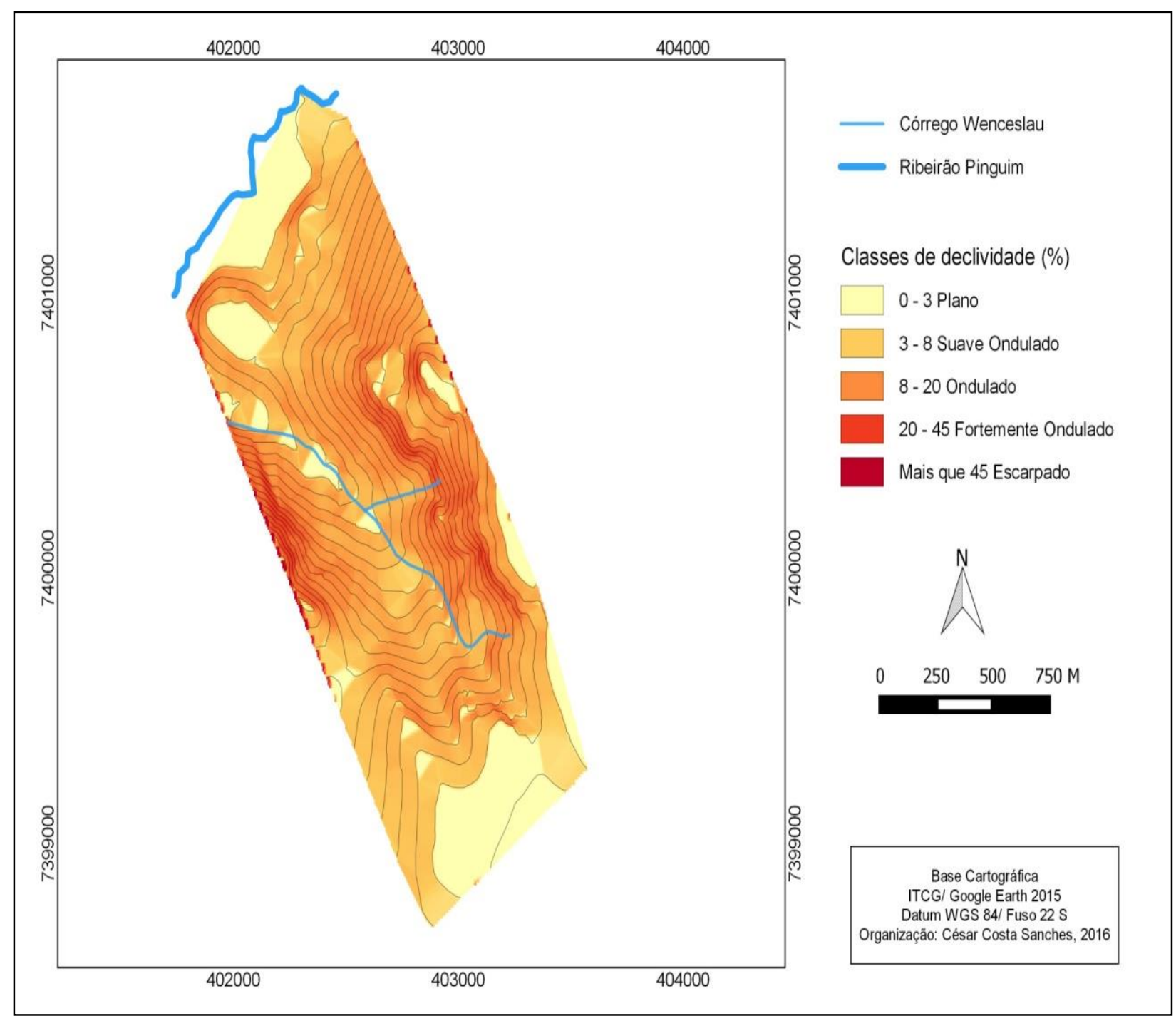

Figura 7. Mapa de declividade da área do Condomínio Green Diamond Residence

A descrição geomorfológica associada a caracterização física e química dos solos fornecem informações detalhadas que são fundamentais para a classificação dos solos, bem como para o planejamento de uso desse recurso ambiental e para sua avaliação.

No que tange aos solos hidromórficos é importante salientar que seu uso e manejo devem considerar suas peculiaridades pedogenéticas, físicas e químicas, garantindo a sustentabilidade da atividade e a conservação dos recursos naturais. (Neto, 2010)

Com base em seu trabalho, o autor ainda expõe que toda forma de utilização do solo pressupõe mudanças à dinâmica pedoambiental, as quais conforme sua intensidade podem acarretar diversos tipos de danos e impactos ambientais, muitas vezes irreversíveis.

Com base nos aspectos geomorfológicos, podemos notar de uma maneira mais prática a situação topográfica da vertente do lote, bem como as áreas que apresentam um relevo mais acidentado e íngreme, ou áreas planas, situadas predominantemente no topo e baixa vertente.

Vale ressaltar que diante da perspectiva abordada no mapa representado pela Figura 8, pode-se notar claramente o entalhamento do leito do córrego Wenceslau.

De acordo com os estudos e levantamentos realizados pelo Instituto Ambiental do Paraná (IAP), por meio da Secretaria de Meio Ambiente e Recursos Hídricos, é apresentado às definições de Solos Hidromórficos com base em suas condições estruturantes e saturação por base. 


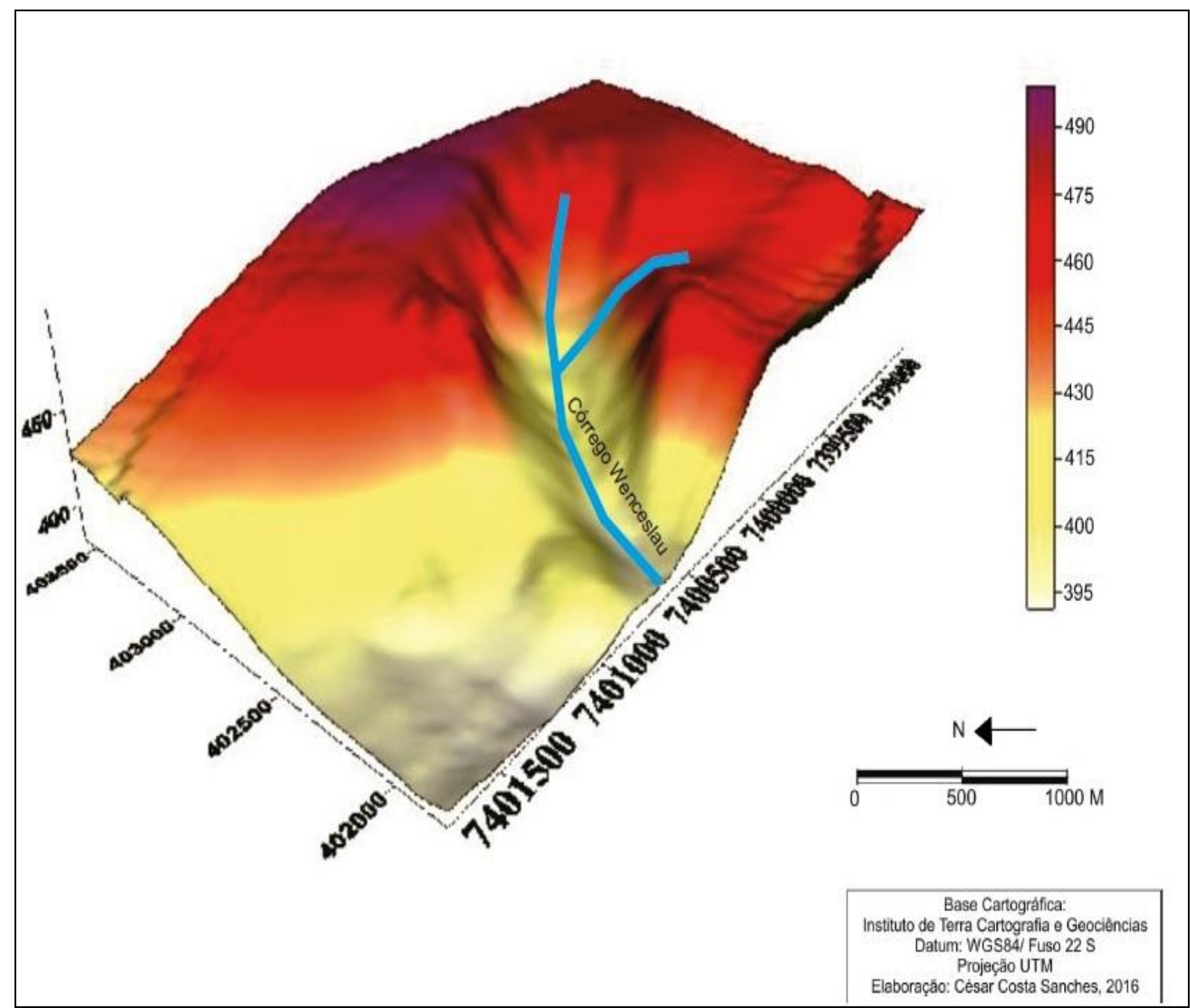

Figura 8: Mapa do modelo da superfície de terreno referente ao empreendimento Green Diamond Residence.

Diante das observações realizadas por meio de tais informações, podemos perceber que perante a Resolução Conjunta IBAMA/SEMA/IAP $\mathrm{N}^{\circ} 005$, de 28 de Março de 2008, Artigo 2, inciso I, entende-se por solos hidromórfico o solo eu em condições naturais se encontra saturado permanentemente ou em determinado período do ano independente de sua drenagem atual e que, em virtude do processo de sua formação, apresenta, comumente, dentro de 50 (cinqüenta) centímetros a partir da superfície, cores acinzentadas, azuladas ou esverdeadas e/ou cores pretas resultantes do acúmulo de matéria orgânica (Figura 9 e 10).

Diante de tais informações Neto, 2010 expõe que estas condições ambientais referentes aos solos hidromórficos estão associadas a áreas de baixada ou depressões localizadas, que apresentam má drenagem decorrente da presença de um lençol freático permanente ou oscilante.

Segundo o autor, diante da perspectiva geográfica, os solos hidromórficos integram ecossistemas aquáticos, apresentando importância ambiental, pela conservação de recursos hídricos e pela manutenção da fauna e da flora. 


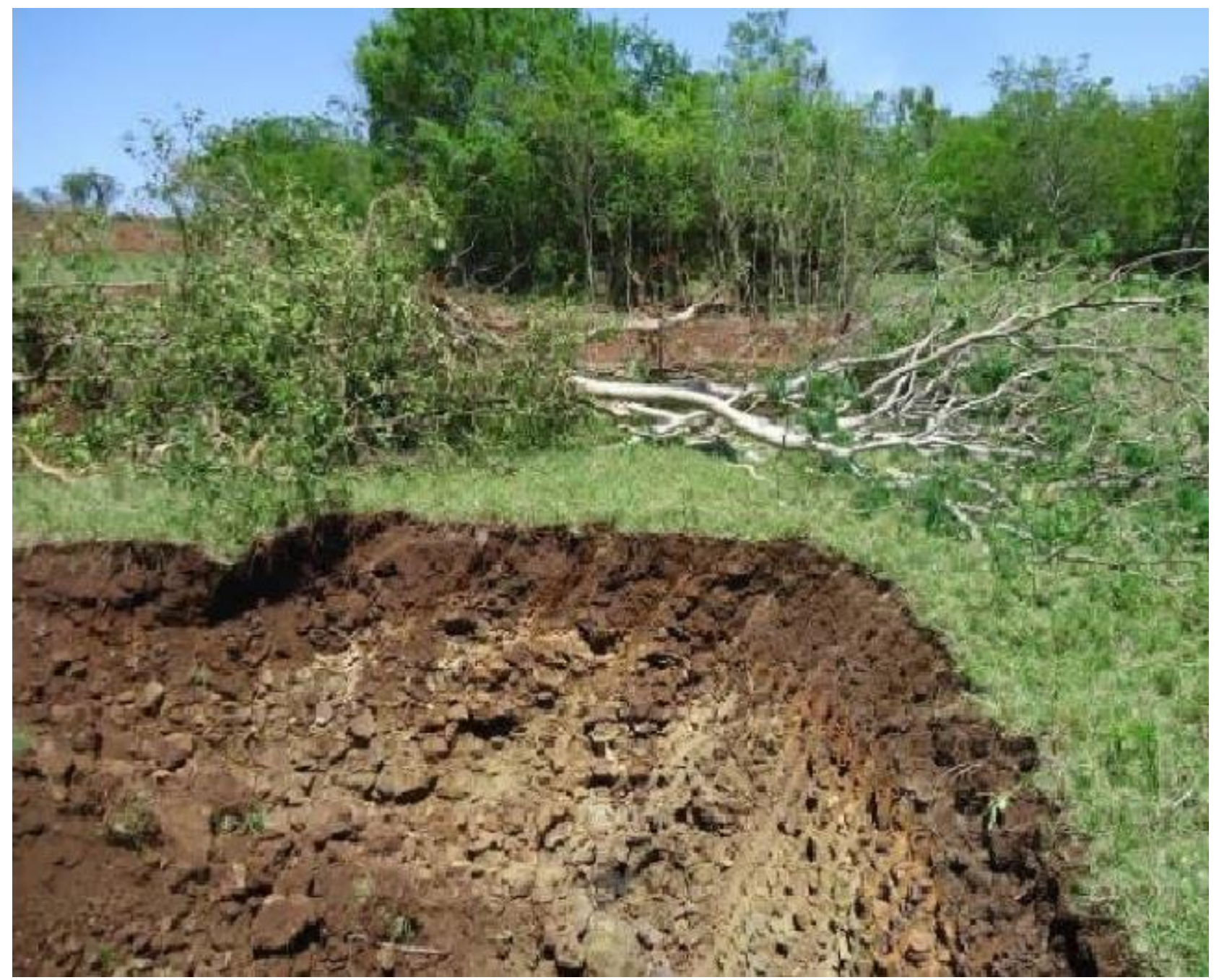

Figura 9. Perfil do solo do empreendimento Green Diamond Residence- Marialva,PR

Fonte: LIMA, Karina Bortolon Pires de; 2012

Sendo assim a realização de praticas e atividades antrópicas executada em tal solo, sem o devido conhecimento prévio das características e propriedades físicas e químicas do solo, as quais são obtidas através de levantamentos pedológicos de aspectos do meio físico, podem acarretar danos e impactos pedoambientais, variáveis conforme o uso e manejo adotados, sendo possível que as mudanças no ambiente desses solos condicionem alterações nas características morfológicas, físicas, químicas e mineralógicas.

Diante dos aspectos pedogenéticos os solos hidromórficos apresentam características e limitações próprias que as diferenciam de outras classes de solos. Originalmente nos primeiros, as características do relevo e a inserção na paisagem proporcionam maior tempo de residência da água nestes solos, devido a restrições de drenagem. (NETO, 2010)

Com base em tais dados, consequentemente desenvolvem-se características morfológicas, físicas, químicas, biológicas e mineralógicas especificas, relacionadas ao processo pedogenético de hidromorfismo ou gleização. (SERRAT, 2002)

No que tange aos aspectos físicos e geomorfológicos da área abordada, podemos analisar a modelagem da superfície do terreno referente á área de estudo, sendo que na Figura 11, é possível compreender a topografia do terreno, com base na representação hipsométrica, fundamentada nas cotas altimétricas situadas no mapa hipométrico, ressaltando também as formas das curvas de nível. 


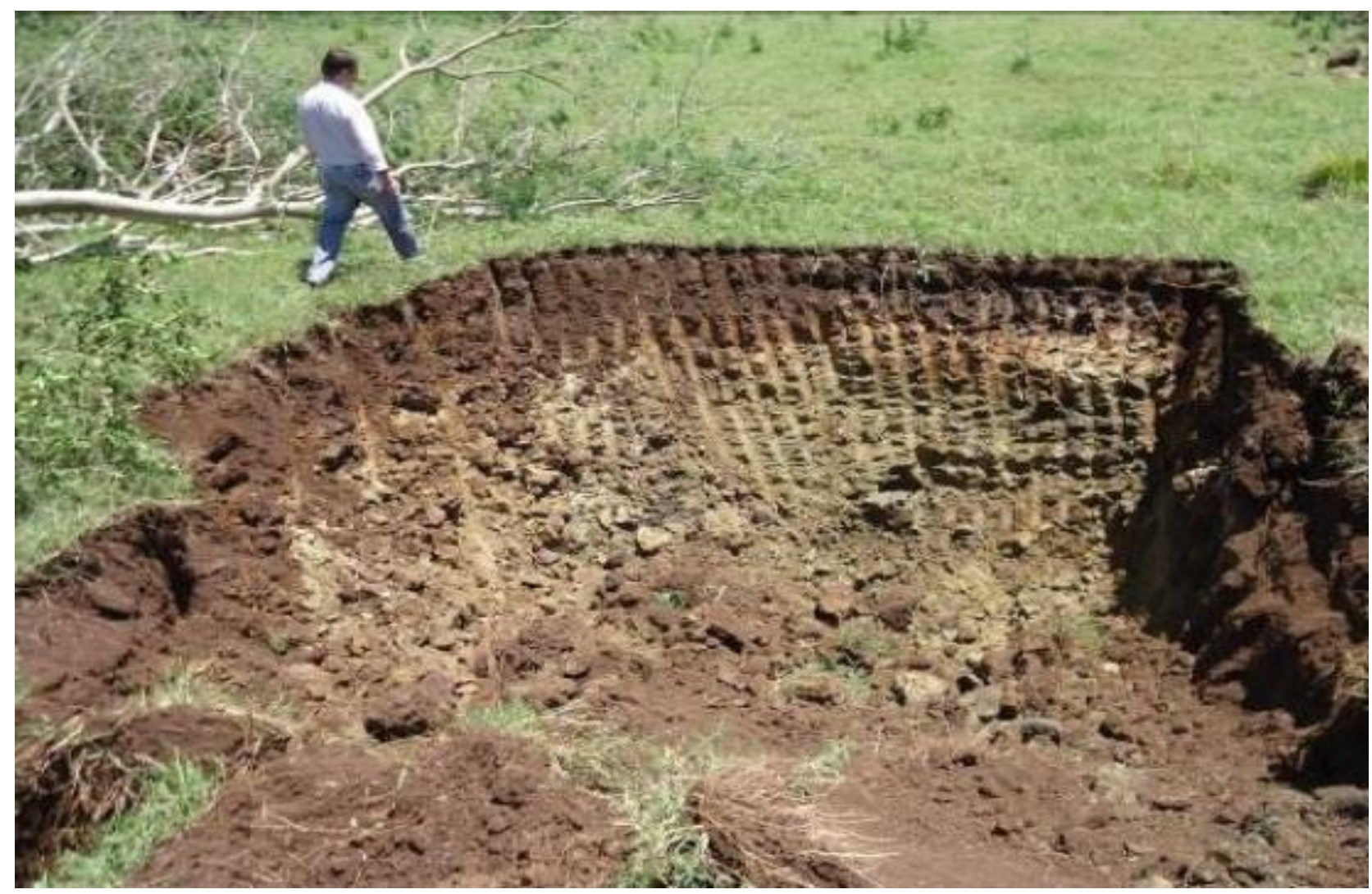

Figura 10. Presença de solo hidromórfico no loteamento Green Diamond Residence- Marialva, PR

Fonte: LIMA, Karina Bortolon Pires de; 2012

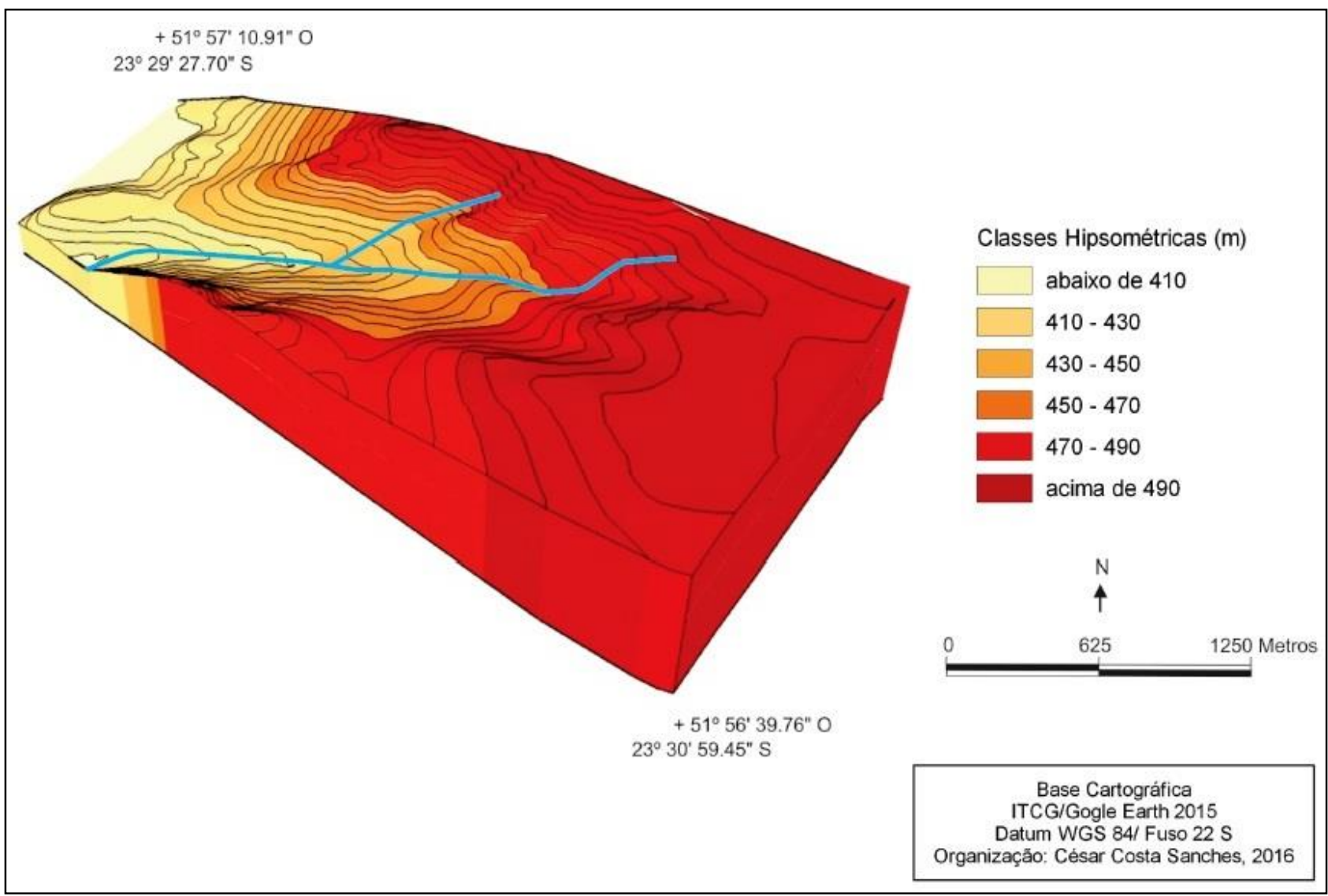

Figura 11: Mapa de modelagem da superfície do terreno do loteamento Green Diamond Residence- Marialva, PR 


\section{Conclusões}

Considerando os aspectos físicos relacionados ao clima, geomorfologia, domínios fitogeográficos, pedologia, a evolução da paisagem, bem como o modelo de superfície do terreno representado por meio das malhas de terreno, especificamente da área abordada, foi possível concluir que não há possibilidades de realizar e construir qualquer tipo de empreendimento para uso civil/ residencial, principalmente nas áreas mais baixas e planas do lote.

Sabe-se que, mesmo possuindo fundamental importância na vida dos seres humanos e na sustentação da vida na Terra, o solo ainda não é, de maneira geral, percebido e valorizado como tal, pois as atividades e interferências antrópicas têm causado diversas consequências devido ao uso e manejo inadequado, desrespeitando suas características e propriedades físicas e químicas, no qual podemos notar suas potencialidades e fragilidades quanto ao seu uso.

Deste modo, percebe-se que devido às características físicas do solo, bem como os aspectos naturais relacionados à geomorfologia $\mathrm{e}$ pedologia da paisagem, nota-se a presença do solo com caráter hidromórfico, devido ao seu aspecto acinzentado próximo a camada superficial do solo, presentes nas imagens referentes às fotos retiradas do local, caracterizando-o a presença permanente ou em determinadas épocas do ano do lençol freático.

Sendo assim a utilização e a realização de empreendimentos civis, ou qualquer outra atividade antrópica mal planejada e sem o conhecimento prévio dos aspectos pedogenéticos do material e das condições naturais da paisagem, em determinado solo, podem acarretar danos e impactos pedoambientais e sociais, conforme o uso e manejo inadequados, possibilitando a ocorrência de alterações ambientais irreversíveis do recurso ambiental solo, condicionando suas estruturas morfológicas, físicas, químicas e mineralógicas.

Com base nas informações e nos dados obtidos, é possível compreender que é de suma importância, para qualquer intervenção do homem, principalmente no recurso ambiental solo, o gerenciamento e planejamento, bem como a avaliação das condições naturais e estruturantes referentes às propriedades físicas, químicas e mineralógicas entre os diferentes elementos da natureza, caso contrário, o uso inadequado pode ocasionar o desequilíbrio no ecossistema ambiental. Para que as práticas e ações antrópicas ocorra de maneira consciente e racional, é fundamental a necessidade de conhecer mais que suas características, a relação e a interação entre seus elementos, compreendendo assim as principais modificações resultantes da ação do homem.

\section{Referências}

Archela, E., França, Valmir de., Celligoi, A., 2003. Geologia, geomorfologia e disponibilidade hídrica subterrânea na bacia hidrográfica do Ribeirão Jacutinga. Revista de Geografia Londrina. V.12- N.2.

Baldwin, M., Kellogg, C. E., Thorp, J., 1938. Soil classification. In: estados unidos. Department of Agriculture. Soils and men. Washington, D.C., P. 979-1001.

BRASIL. 1988. Constituição da República Federativa do Brasil.

BRASIL. 2011. Lei Complementar nº111, de 01 de fevereiro.

BRASIL. 1979. Lei n ${ }^{\circ} 6.664$, de 26 de junho.

BRASIL. 1981. Lei ${ }^{\circ}$ 6. 938, de 31 de Agosto

BRASIL. 1986. Resolução CONAMA nº 001, de 18 de junho.

BRASIL. 2005. Resolução CONAMA n ${ }^{\circ} 357$, de 13 de março.

BRASIL. 2011. Resolução CONAMA n 430, de 18 de maio.

BRASIL. 2008. Resolução Conjunta IBAMA/SEMA/IAP de 28 de Março

BRASIL. 1986. Resolução CONAMA Nº 001 e 001-A/86.

BRASIL. 2007. Resolução CONAMA No 237/97.

Campos, J. B., Silveira-Filho, L., 2010. Série Ecossistemas Paranaenses: Floresta Estacional Semidecidual. V.5. Curitiba, PR. 8 p .

Estação Convencional: Maringá (PR). Disponível em:http://www.inmet.gov.br/sim/sonabra/dspd adoscodigo.php?ODM3Njc=. Acesso em: $27 \mathrm{de}$ janeiro de 2016.

EMBRAPA. Empresa Brasileira de Pesquisa Agropecuária, 2006. Sistema Brasileiro Classificação dos Solos. 2a . Ed- Rio de Janeiro. 
EMBRAPA. Empresa Brasileira de Pesquisa Agropecuária, 2006. Cultivo do Arroz de Terras Altas no Estado de Mato Grosso. Disponível em:https://sistemasdeproducao.cnp tia.embrapa.br/fonteshtml/Arroz/arrozterrasalta smatogrosso/solos.htm. Acesso em 3 de janeiro de 2016

EMBRAPA. Empresa Brasileira de Pesquisa Agropecuária, 1997. Manual de métodos de análise de solo. 2.ed. Rio de Janeiro.

EMBRAPA. Empresa Brasileira De Pesquisa Agropecuária, 2008. Centro Nacional de Pesquisa de solos. Mapa de Solos do Estado do Paraná. Rio de Janeiro.

Estudos Ambientais Preliminares / Editais de entrada e abertura de prazos - 2013. Disponível em: http://www.iap.pr.gov.br/. Acesso em 02 de maio de 2015.

Estudo de Impacto Ambiental (Eia)/Relatório De Impacto Ambiental (Rima). Disponível em:http://www.fepam.rs.gov.br/central/pdfs/eia rimainstabril2002.pdf. Acesso em 23 de maio de 2015.

Hartemink, A. E., Bockheim, J.G., 2012. Soils Genesis and classification. University of Wisconsin-Madison, Department of Soil Science, FD Hole Soils Lab. p.441-441.

Köppen, W., Geiger, R., 1928. Klimate der Erde. Gotha: Verlag Justus Perthes.

Lepsch, Igo F. 2012. Formação e conservação dos solos. - $2^{\mathrm{a}}$ ED. - São Paulo: Oficina de Textos.p. 216.

LIMA, K. B. P. de., 2012 Juntada de Petição de inicial. Arq: Doc. 8 - B Fotografias. 18 de outubro.

Maack, R., 1968 Geografia Física do Estado do Paraná. Curitiba: BRDE, 350 p.

MINEROPAR. 2006. Atlas Geomorfológico do Estado do Paraná. Universidade Federal do Paraná, Curitiba, 63 p.

MINEROPAR. 2001. Atlas Geológico do Estado do Paraná. Minerais do Paraná, Curitiba., 125 p. CD ROM.
Neto, L. de F. da S., 2010. Pedogênese e matéria orgânica de solos hidromórficos da região metropolitana de Porto Alegre. Tese (Doutorado em Ciência do solo). Porto Alegre. Universidade Federal do Rio Grande do Sul.

Neto, J. P. de Q., 2003. Geomorfologia e Pedologia. GEOUSP Espaço e Tempo, nº 13, p. 9-20.

Neto, J. P. de Q., 1987. Pedologia: Conceito, Método e Aplicações. Revista do Departamento de Geografia da USP. n 3. 95-102

Instituto de Terras, Cartografia e Geociências (ITCG), 2009. Classificação Climática - Estado do Paraná. Disponível em: < http://www.geo.pr.gov.br/ms4/itcg/geo.html>. Acesso em 17 de setembro de 2013.

Instituto de Terras, Cartografia e Geociências (ITCG), 2009. Formação Fitogeográfica Estado do Paraná. Disponível em: < http://www.geo.pr.gov.br/ms4/itcg/geo.html>. Acesso em 17 de setembro de 2013.

Instituto de Terras, Cartografia e Geociências (ITCG), 2009. Unidades Morfoestruturais Estado do Paraná. Disponível em: < http://www.geo.pr.gov.br/ms4/itcg/geo.html>. Acesso em 17 de setembro de 2013.

Instituto de Terras, Cartografia e Geociências (ITCG), 2009. Solos - Estado do Paraná. Disponível em: < http://www.geo.pr.gov.br/ms4/itcg/geo.html>. Acesso em 17 de setembro de 2013.

Santos, H. G. dos., Jacomine, P. K. T., Anjos, L. H. C. dos., Oliveira, V. A. de., Lumbreras, J. F., Coelhos, M. R., Ameida, J. A. de., Cunha, T. J. F., Oliveira, J. B. de., 2013. Sistema Brasileiro de Classificação de Solos. $3^{\text {a }}$ Ed. Revista. Ampli.- Brasília, DF. 353 p.

Secretaria do Meio Ambiente e Recursos Hídricos. 2015. Licenciamento de serviços - Áreas Úmidas - Definições. Disponível em: http;//www.iap.pr.gov.br/modules/conteúdo/co nteúdo.php?Conteudo=280. Acesso em $20 \mathrm{de}$ maio de 2015

Serrat, B. M., Lima, M. R. de., Garcias, C. E., Fantin, E. R., Carnieri, I. M. R. S. A., Pinto, L. S., 2002. Conhecendo o solo. Curitiba: Departamento de Solos e Engenharia Agrícola, $27 \mathrm{p}$. 
Revista Brasileira de Geografia Física v.11, n.04 (2018) 1384-1400.

Simonson, R. W., Riecken, F. F.; Smith, G. D., 1952. Understanding Iowa soils: an introduction to the formation, distribution and classification of Iowa soils. Dubuque: C. Brown, 142 p.
Thorp, J., Smith, G.D., 1949. Higher categories for soil classification. Soil Science 67:117-126. 